\title{
ФАКТОРИ МОТИВАЦИЈЕ И УТИЦАЈ НОВИХ ТЕХНОЛОГИЈА У ПРОЦЕСУ УЧЕЊА МОДЕРНОГ ГРЧКОГ КАО СТРАНОГ ЈЕЗИКА
}

Циљ овог рада је да даิ осврт на факторе које могу утицати на мотивацију студената у процесу учења модерног грчког као страног језика. Посебна пажња посвећена је иницијалној жељи студената по питању студија, као и доприносу коришћења нових технологија, конкретније Мудл платформе у настави. У циљу испитивања наведених фактора спроведено је истраживање међу студентима неохеленистике Филолошког факултета Универзитета у Београду. Приказана анализа резултата упитника указује на значај нових технологија у настави, на допринос квалитета студија и материјала као и на улогу предавача у повећању мотивације за наставак учења и бављења модерним грчким језиком.

Кључне речи: мотивација, модерни грчки језик, Мудл платформа, ситуација учења.

\section{1. Увод}

Мотивација се може издвојити као један од водећих фактора који утичу на људско понашање, па и на процес учења и усвајања једног језика. Она пружа примарни подстрек за учење Л2, као и за наставак учења као континуираног процеса, а сматра се важним фактором чак и за појединце са значајним способностима, који без мотивације не могу постићи дугорочне циљеве (Дерњеј 2005:65).

* antonina.irini@gmail.com 
Истраживачи наводе да утицај на мотивацију могу имати личне карактеристике, као што су језички ниво који особа поседује (Дерњеј 1990:7), њен пол (Кисо 2006:74), као и фактори везани за ситуацију учења, у које је у данашње време значајно убројити ефекат нових технологија у настави (Степ-Грини 2002:165). Током дугог процеса савладавања одређеног предмета мотивација не остаје константна, већ је повезана са динамички променљивим менталним процесом, који одликује стална процена и стварање равнотеже између различитих унутрашњих и спољашњих утицаја којима је појединац изложен (Дерњеј, Скехан 2003:617). Тако на иницијалну жељу и циљ који појединац поседује могу утицати разни фактори који доводе до промена у динамичном процесу усвајања страног језика.

\section{2. Мотивација и усвајање Л2 језика}

Дерњеј (Дерњеј 2001a:44) наводи да је, у неким почетним истраживањима о мотивацији, она посматрана као релативно стабилна карактеристика студента која је повезана са три ствари: са перцепцијом о другом језику и његовим говорницима, која се огледа у језичким ставовима, са ставовима према ситуацији учења језика, као што су курс или предавач, и са међунационалним контактом и самоувереношћу студента која из тога проистиче.

Гарднер (Гарднер 2000:15) је креирао модел у оквиру ког је поделио варијабле које утичу на учење страног језика у четири категорије: интегративност, ставови према ситуацији учења, мотивација и друге варијабле. Како образлаже, интегративност се може посматрати као отворено интересовање према језичкој групи. Ставови према ситуацији учења се посматрају као реакција на контекст учења језика који би могао укључити ставове према општем школском окружењу, реакције на текстуалне материјале итд., али се пре свега тичу евалуације предавача и језичког курса. Намера ове категорије је да објасни варијације у складу са ситуацијом, будући да се испоставило да емоционалне реакције појединца могу утицати на његово усвајање језика (Гарднер 2000:15). 
Гарднер (Гарднер 2000:16) поставља хипотезу према којој интегративност и ставови према ситуацији учења не утичу директно на усвајање језика али стварају основу мотивације појединца за учење. Истраживање које је спровео фокусирало се на интензитет мотивације, односно на то колико се ученик трудио да научи страни језик. Касније је установљено да је мотивација много више од самог интензитета, па је додата и компонента жеље за учењем. Што се осталих варијабли тиче, Гарднер (Гарднер 2000:16) издваја инструменталну мотивацију, за коју наводи пример појединца који жели да научи језик ради добијања посла, дакле фокус ставља на проширење каријерних могућности.

Клемент (Клемент 1980, цитирано у Гарднер и др. 2004:2) својим друштвеним контекстуалним моделом такође фокус ставља на интегративну мотивацију, али издваја друштвени контекст као значајан фактор за развој мотивације за учење другог језика и тврди да позитивна искуства са језиком чине студенте самоуверенијим и развијају њихову интегративну мотивацију. На сличан начин Брофи (Брофи 2013:15) објашњава да се мотивација може описати као „тенденција ученика или студента да академске активности сматра смисленим и вредним труда, те настојање да из њих извуче планиране академске користи“, па стога може бити и општа црта и стање у одређеној ситуацији.

Како Дерњеј (Дерњеј 1990:6) наводи, то да ли је појединац инструментално или интегративно мотивисан не утиче значајно на његов успех у учењу, односно и један и други тип мотива имају сличан утицај. Такође, ова разлика не утиче ни на жељу појединца да настави да учи одређени језик. Закључено је да је важан утицај на интегративне мотиве има употреба језика изван оквира наставе, јер је ова жеља у вези са позитивним ставом према странцима, односно показује њихову „интернационалну отвореност“ (Дерњеј 1990:6).

Најчешће, ученик Л2 не поседује само једну, већ две или више врста мотивације које се допуњују и заједнички утичу на усвајање (Костић 2018:131). Тако резултати анкете коју је 
спровела Хорњак (Хорњак 2012:450) указују на то да студенти шпанског језика поседују и интегративну и инструменталну мотивацију, које позитивно утичу на учење страног језика, док су слична истраживања спроведена и у случају грчког језика 1 .

Резултати истраживања које је спровео Клемент (Клемент и др. 1994:443) потврђују релевантност приступа социјалних фактора у разумевању мотивације при усвајању другог, страног језика и показују значај динамике групе за стварање бољег окружења за учење. Како Дерњеј (Дерњеј 2005:90) тврди, динамика групе може у великој мери утицати на мотивацију појединца, док се демотивација јавља када у групи постоји негативна атмосфера и може исту ту мотивацију редуковати. Такође, одређена истраживања (Јулкунен 1989) су истакла значај фактора везаних за учионицу и за специфичну ситуацију, која може утицати на учење страног језика (Клемент и др. 1994:423). Како Дерњеј (Дерњеј 2005:75) наводи, на ученике страног језика и њихову жељу за учењем значајно утиче квалитет програма и наставе.

\section{1. Утицај нових технологија на усвајање Л2}

У данашње време дешавају се многе промене у области учења, будући да нове технологије и нови начини подучавања могу да утичу на мотивацију ученика у процесу учења. Како истраживачи тврде, нове методе укључују повећање мотивације због учења фокусираног више на самог ученика и његовог укључивања у наставни процес (Браунли-Кониерс 1996; Двајер 1996), што резултује бољим резоновањем и бољим памћењем (Степ-Грини 2002:165).

Може се приметити и значај мултимедија, посебно у случају мање успешних ученика, јер им помаже у илустровању концепата и организовању информација (Новацик 1998:368). Истраживања показују да се ученици осећају самоуверено када утичу на

1 Уп. Стојичић, Мутавџић 2011; Милојевић 2011; Стојичић, Гогас 2012; Стојичић 2013. 
процес учења, као што је случај са интерактивним окружењима при самосталном учењу (Степ-Грини 2002:165). У случају учења језика, нове технологије доносе бенефите у смислу развијања самосталне иницијативе при учењу језика и преношењу веће одговорности на ученике када је реч о постизању боље језичке компетенције, као и ширењу културне свесности (Санауи, Лапкин 1992, цитирано у Степ-Грини 2002:166).

Келнер (Келнер 2002:94) истиче чињеницу да се велики део потенцијала који поседују технологија и нови медији огледа у њиховој образовној улози. Високошколске установе у разним земљама све више усвајају online образовање али иако су одређене институције већ усвојиле овај начин преношења знања, друге много спорије прихватају промене ${ }^{2}$ (Ким, Бонк 2006:29). Тако се и наставници могу поделити на три групе, на оне који лако прихватају иновације, оне који са резервом прихватају промене и оне који веома тешко мењају своје навике (Солдатић и др. 2012:37).

Могуће препреке приликом коришћења online курсева су недостатак дисциплине студената када приступају интернету, чињеница да факултети не прихватају у довољној мери овај тип наставе, као и велики трошкови везани за развој и спровођење ове методе (Ален, Симан 2007:3). Додатни трошкови могу постојати због повећања ангажовања наставника, техничке подршке, инфраструктуре, одржавања, лабораторија за снимање, неопходне опреме итд. (Солдатић и др. 2012:48). Постоје многи елементи који утичу на задовољство ученика

2 Када је у питању Филолошки факултет Универзитета у Београду, промене су уведене и у припреми за полагање пријемног испита за додипломске студије, по први пут 2011. године, за италијански, шпански и грчки језик. Аутори наводе да је увођење информационих и комуникативних технологија у припрему представљало изазов (технички и организациони), али је дало значајне резултате, будући да је од наредне академске године почело шире да се примењује и на другим катедрама. Када је реч о полазницима припремног курса, изразили су у великој мери задовољство, док се показала и ефикасност оваквог приступа учењу, будући да су сви успешно положили пријемни испит (Солдатић и др. 2012:44-45). 
када се њихово учење одвија у online окружењу. Као три кључна фактора могли би се издвојити инструктор, технологија и интерактивност (Болигер, Василик 2004:63).

Путем интернета предавачи и студенти имају приступ многим изворима, платформама и алатима који олакшавају и унапређују процес учења. Једна од платформи која се све чешће употребљава у образовним институцијама је Moodle (Myдл), који омогућава ученицима страног језика да на ефективан начин користе технологију. Мудл је креирао 1999. године Мартин Дујамас (Martin Dougiamas), администратор на „Curtin“ Универзитету у Аустралији. Данас ова платформа поседује преко 150 милиона корисника ${ }^{3}$ и креирана је на начин да буде доступна просечном кориснику који поседује основни ниво познавања технологије (Јаман, Арслан 2011:444).

Иако многе образовне установе данас користе интернет у сврху предавања и учења, поље фактора који утичу на задовољство ученика при коришћењу платформе Мудл платформе није довољно истражено (Санчез, Уерос 2010:1633). Студија коју су спровели Санчез и Уерос (Санчез, Уерос 2010), а везана је за Мудл, показује да је техничка подршка веома значајна и да ствара код ученика перцепцију о већој лакоћи коришћења и о корисности, па је, како они наводе, веома значајно да корисници буду обучени и припремљени. Не само студенти, већ и наставно особље треба да има приступ адекватној обуци 4 . Као значајан се истиче и допринос предавача који треба да пружају

3 https://moodle.net/stats/

4 Примена комбинованог учења учења на Филолошком факултету БУ почела је 2010. године, док се платформа Мудл показала као најбољи избор. Како је Солдатић (Солдатић 2016) навела, према подацима из 2016. године, на Филолошком факултету је постојало укупно 8675 корисника платформе, од којих су 123 предавачи и 67 стручни сарадници. Платформа је у том тренутку располагала са 390 курсева, 320 са OAC, 43 са MAC и 27 са ДАС. IT сектор факултета организује сваке године обуке које предавачима помажу у коришћењу платформе и прилагођавању дидактичких материјала, будући да је развијање курсева индивидуално, а не централизовано по студијским профилима. Иницијално су организоване обуке за постављање материјала, док је данас највећи број предавача заинтересован за обуку за израду тестова. 
подршку у коришћењу платформе и разреше могуће недоумице студената (Санчез, Уерос 2010:1639).

\section{3. Истраживање}

Спроведено истраживање за циљ је имало испитивање мотивације студената прве и друге године студија на Катедри за неохеленске студије Филолошког факултета БУ. Истраживање је обављено у јуну 2018. године на Катедри за неохеленске студије универзитета у Београду и за његове потребе коришћен је упитник који је креиран путем Google Forms странице ${ }^{5}$, а студенти су његовом попуњавању приступили истовремено, путем рачунара на Филолошком факултету. Упитник се састојао од 36 питања, подељених у три дела. Одређени делови упитника преузети су из анкете са сличном тематиком која је спроведена на Катедри за неохеленске студије 2011. године ${ }^{6}$, док је преостала питања креирала ауторка рада, како би упитник био прилагођен циљевима конкретног истраживања.

Први део упитника је био општег карактера и састојао се од 10 питања везаних за узраст, пол и дотадашњи контакт са Грчком и грчким језиком. Други део састојао се од 11 питања и био је подељен у две категорије, у зависности од одговора који су студенти дали на последње питање првог дела - да ли је иницијална жеља студента била да упише студије неохеленистике или не. Други део, чијом се анализом бави овај рад, фокусирао се на ставове о грчком језику, задовољство студијама и појединим елементима студија, као што су предавачи, материјали или колеге, опадање или повећање мотивације за студирање у односу на почетак студија, као и на перцепцију могућности које се пружају у будућности, након завршетка студија. Упитником је истражен фактор иницијалне жеље за уписивање студија неохеленистике и његов утицај на мотивацију док је један део посвећен доприносу увођења нових технологија у наставу.

5 https://bit.ly/2XN6DN6

6 Велику захвалност дугујемо доц. др Војкану Стојичићу, који је уступио модел анкете коришћене овом приликом. 
У истраживању је учествовало 67 студената неохеленистике (прва година студија: 41.8\%, друга година студија: 58,2\%, мушки пол: 20,9\%, женски пол: 79,1\%).

\section{1. Фактори мотивације}

Као што смо навели, мотивација је најчешће скуп различитих утицаја који усмеравају особу као остварењу одређеног циља. Дерњеј (Дерњеј 2001a:44) је навео да је мотивација повезана са перцепцијом о другом језику и говорницима, нешто што је у нашој студији истражено постављањем питања везаних за са̂м језик и за језичку заједницу. Став према језику се у нашој студији показао као значајан, јер 73,1\% испитаника сматра да је грчки језик мелодичан, док $68,6 \%$ испитаника сматра да је леп. Негативан став се знатно мање појављује, па тако $28,3 \%$ сматра да је језик тежак, $16,4 \%$ да је превише обиман, док није било испитаника који су навели да сматрају да је језик досадан. Ипак, више је било испитаника који су навели тежину језика него његову лакоћу (6\%).

Дерњеј такође истиче ставове према ситуацији учења. Ови ставови се посматрају као реакција на окружење учења, материјале, али пре свега предаваче и језички курс (Гарднер $2000: 15)$. Из тог разлога, наше истраживање је испитало и ниво задовољства како програмом, учионицом и градивом, тако предавачима и колегама студентима. Одговори су представљени у табели која следи. 
Табела бр. 1 - Задовољство елементима студија

\begin{tabular}{|l|l|}
\hline Задовољан/на сам: & Предавачима: 85\% \\
& Коришћењем платформе Мудл: 77,6\% \\
& Учионицом: 67,1\% \\
& Колегама студентима: 58,2\% \\
& Организацијом наставе: 53,7\% \\
& Интерактивном наставом: 43,3\% \\
& Градивом: 35,8\% \\
& Приручницима: 32,8\% \\
& Тежином курсева: 14,9\% \\
\hline Нисам задовољан/на: & Тежином курсева: 61,2\% \\
& Градивом: 20,9\% \\
& Организацијом наставе: $16,4 \%$ \\
& Приручницима: 10,4\% \\
& Коришћењем платформе $M y д л: 6 \%$ \\
& Колегама студентима: 6\% \\
& Интерактивном наставом: 3\% \\
Предавачима: $1,5 \%$
\end{tabular}

Може се закључити да постоји много веће задовољство ситуацијом учења, у односу на незадовољство, па се и овде може навести позитиван утицај на мотивацију за учење језика. У склопу студија постоје велика очекивања од студената, као што су усвајање градива, језичких вештина, као и развијање флуентности ради коришћења језика ван наставе (Гарднер 2001:4). Стога не чуди што је наше истраживање показало највеће незадовољство тежином курсева. Нешто што се показало такође као значајан предсказатељ наставка учења језика је квалитет самог програма и наставе (Дерњеј 2005:75). Како је ова димензија од значаја за одржавање мотивације, наше истраживање испитало је и задовољство организацијом наставе, за које су резултати показали да је на добром нивоу, па можемо рећи да иде у прилог развоју и одржавању жеље за даљим усвајањем језика.

Начин на који се знање преноси засигурно може утицати на мотивацију студената, јер је, без обзира на компетентност предавача, неопходно да његова предавања буду јасна и створе 
базу за развијање мотивације (Дерњеј 2001б). Тако се и у нашем истраживању показало да постоји генерално задовољство предавачима, нешто што може даље подстаћи мотивацију студената за учење. Осим тога, однос према колегама студентима се може сматрати као значајан јер се у истраживањима показало да динамика групе може значајно утицати на мотивацију, као и на демотивацију појединца у случају негативне атмосфере (Дерњеј 2005:90). Можемо приметити да и у овом сегменту постоји доста висок ниво мотивације који може служити као могући подстрек путем позитивне атмосфере у групи.

Упитник је укључио и питања која су за циљ имала испитивање перцепције студената о вредности студија, односно могућностима које се пружају након њиховог завршетка. Чак 64,2\% укупног броја испитаника навело је да сматра да „и у Србији и у иностранству постоје многе прилике за рад са грчким језиком“, док мањи број (19,4\%) сматра да „не постоје прилике за рад само са грчким језиком, без усавршавања у другој области“. Укупно 10,4\% сматра да „само у Грчкој постоје прилике за рад са грчким језиком“ а 6\% да „прилике за рад са грчким језиком постоје у иностранству, али не у Србији“. Резултати су показали да већина студената, без обзира на претходни контакт са језиком, или на годину студија, сматра да постоје многе прилике за рад са грчким језиком, па се може извести претпоставка да њихова перцепција будућности и вредности студија позитивно утиче на њихову мотивацију.

\section{2. Утицај нових технологија - платформе Мудл}

Како истраживања показују, ученици се осећају самоуверено када утичу на процес учења, као у случају интерактивних окружења при самосталном учењу (Степ-Грини 2002:165). У склопу нашег истраживања испитали смо колико задовољство технологијом, у нашем случају Moodle платформом, као и интерактивношћу, позитивно утиче на мотивацију студената. Moodle платформа се у последње четири године веома активно 
користи на Катедри за неохеленске студије као подршка класичној настави. Још од 2010. године студенти имају могућност да приступају додатним материјалима путем платформе, али је у последње четири године постала неизоставан елемент наставе, помоћу којег се евидентира присуство студената, прати градиво и полажу се колоквијуми и испити. На овај начин је структура наставе знатно промењена, пружајући један нови, интерактивни елемент.

Значајно је напоменути да је на Катедри за неохеленске студије 2011. године спроведена анкета која се такође бавила задовољством студената и њиховом мотивацијом (Стојичић 2013:460). Анкета је обухватила 50 студената прве године и рађена је у папирној, писаној форми, за разлику од наше анкете, рађене преко рачунара и Google Forms платформе. Резултати те анкете показали су да је већина испитаника сматрала да је грчки језик веома тежак али су навели да су их професори, занимљиви приручници и лепота језика мотивисали да га усвоје. Такође, показало се да су студије уписали већим делом због лепоте језика и културе, а не због могућности лаког запослења са знањем језика.

Постоје одређене разлике између резултата добијених у наведеној анкети и наших резутата. Наиме, чини се да су испитаници мотивисанији приликама које пружа грчки језик након завршетка студија, јер је наша анкета показала веома позитиван став када је реч о запослењу, као и да на њихову мотивацију значајно утиче интерактивност и коришћење Moodle платформе у настави, нешто што није постојало као могућност у време када је претходна анкета спроведена, осам година раније. У нашој анкети, као што смо већ навели, један од сегмената за које су анкетирани студенти исказали највеће задовољство је управо Moodle платформа, будући да 77,6\% истиче како је њом задовољно, а само 6\% да није. Такође, 43,3\% студената наводи да је задовољно интерактивном наставом, а само 3\% да није. Можемо закључити да увођење ове платформе у наставу доприноси стварању позитивне перцепције студената о језику и студијама и служи као одличан алат који им помаже у савладавању градива. 
На Катедри за неохеленске студије је 2018. године спроведено још једно истраживање (Петковић 2018) у вези са коришћењем платформе Мудл у настави. Анкетирани студенти су исказали своје ставове о курсевима Савремени грчки језик и Практикум из неохеленистике. Показало се да већина испитаника садржаје за оба курса на платформи сматра веома корисним и да је у великој мери задовољна начином на који су материјали организовани. Анкета је такође показала да је половина испитаника још увек више наклоњена традиционалним материјалима, у поређењу са комплетном дигитализацијом наставе, док је изузетно позитивно оцењена израда колоквијума и испита путем платформе Мудл, посебно због могућности тренутног сазнавања резултата. Значајно је такође навести да је већина испитаника навела да је уз помоћ курсева на платформи напредовала када је реч о нивоу језичке компетенције (Петковић 2018). Сличне резултате показало је истраживање које је на Катедри за неохеленске студије спроведено 2017. године а тицало се активности разумевања слушаног текста. Резултати су показали да студенти друге године препознају корисност платформе Мудл (80\%) јер путем ње имају прилику да приступе вежбама и раде на овој активности. Ипак, велики број учесника анкете $(77,14 \%)$ наводи да им више одговара да писмене провере раде у папирној форми, у односу на online верзију, будући да током тестирање језичке активности слушања могу да прибележе одређене сегменте, што није могуће када се решавању упитника приступа путем рачунара (Стојичић, Ламбропулу 2018:90).

\section{3. Иницијална жеља за уписивање студија}

Још један циљ који је наше истраживање имало тиче се везе између иницијалне жеље за уписивање неохеленских студија и мотивације која се јавља у току студирања. Многи студенти Филолошког факултета не упишу језик који су иницијално желели, већ своју одлуку заснивају на другим факторима, будући да за њих, због осталих пријављених кандидата, није било места на језику за који су се примарно интересовали. Наше ис- 
траживање је покушало да закључи да ли након уписивања неохеленских студија постоји разлика у мотивацији студената чија су прва жеља ове студије (у даљем тексту - група А) и оних који су се за студирање на овој катедри одлучили касније, из других разлога (у даљем тексту - група Б).

Када је реч о ставу према језику, можемо приметити да се код обе групе као примаран одговор може издвојити „веома ми се допада“, док већи број испитаника групе А наводи да је грчки језик онај који највише воле. Занимљиво је приметити да ни у групи А, ни у групи Б нема испитаника који наводе да им се језик не допада, односно није било испитаника који су одабрали одговоре „нити ми се допада, нити ми се не допада, равнодушан/шна сам“, „не допада ми се уопште“ и „немам став“. Из ових одговора можемо закључити да постоји разлика у ставу према језику, не знатно велика, али довољна да се може приметити да је више испитаника којима је грчки језик био прва жеља усмерено на њега и бира га као свој омиљени језик, док остали студенти грчки воле али не искључиво, дајући можда предност неком другом језику, који је био њихов први избор.

Испитаници су упитани о разлозима из којих имају овакав став о језику, па су имали могућност избора више понуђених одговора. Већина испитаника групе А означила је лепоту језика $(80,8 \%)$, док ово није био примаран одговор групе Б, која је предност дала мелодичности $(70,7 \%)$. Када се ради о негативним карактеристикама, израженије су код групе Б $(15,4 \%$ испитаника групе А наводи да је језик тежак и 7,7\% да је превише обиман, док то чини 36,6\% групе Б по питању тежине и $22 \%$ по питању обимности) (Костић 2018:138). На основу ових одговора могло би се претпоставити да особе које нису поседовале иницијалну мотивацију за учење наилазе на веће препреке у савладавању тог језика и доживљавају га као сложенији. Можемо претпоставити да се овакав став на каснијим годинама студија може променити, у складу са постигнутим нивоом знања и евентуалном променом ставова код групе Б.

Одговори на питање о студијама, односно о тренутном осећају исправности одлуке за студирање неохеленистике су 
се показали као веома позитивни. Када су упитани да ли се кају што су уписали ове студије, испитаници су углавном негативно одговорили (А:96,2\%, Б:92,7\%) и ту не можемо приметити разлику између две групе. Када су испитаници изражавали задовољство студијама, бројевима од 1 до 5, није било оних који су означили бројеве 1 и 2. Занимљиво је међутим приметити да је у групи А већи број испитаника своје задовољство оценио бројем 5 (А: 53,8\%, Б: 39\%).

Веома позитивни резултати су се показали и у случају повећања интересовања и мотивације. Обе групе су већином изјавиле да је њихово интересовање за грчки језик веће у односу на почетак студија (A: 73,1\%, Б:78\%), неколицина је изјавила да је исто (А:15,4\%, Б:17,1\%) а да је интересовање мање у групи А је изјавило $11,5 \%$ и у групи Б $4,9 \%{ }^{7}$. У овом случају не постоје значајне разлике и примећујемо да постоји раст интересовања без обзира на иницијалну жељу, чињеница која говори о квалитету студија и мотивисању студената током њих.

Када се упореди задовољство одређеним сегментима студија, у случају већине испитаника не постоји значајна разлика. Највеће задовољство су испитаници обе групе изразили поводом професора (А:84,6\%, Б:85,4\%), коришћења платформе Мудл (А:80,8\%, Б:75,6\%), учионице (А:69,2\%, Б:65,9\%) и колега студената (А:65,4\%, Б:53,7\%). Мала разлика се може приметити у задовољству организацијом наставе (А:61,5\%, Б:48,8\%) и приручницима (А: 42,3\%, Б:26,8\%). Такође, разлика постоји и када је реч о задовољству везаном за тежину курсева (А:26,9\%, Б:7,3\%). Дакле, као и у случају тежине језика, можемо приметити да се перцепција о тежини курса везује за иницијалну мотивацију студената, где је могуће да студенти који нису били иницијално мотивисани сматрају да ће теже савладати градиво. Ова констатација се ипак не може до краја потврдити, будући да су испитаници обе групе, када су упитани чиме нису задовољни на студијама, углавном изразили незадовољство поводом тежине курсева (А:53,8\%, Б:65,9\%), док је одређени

7 У неком будућем истраживању би могли да се истраже разлози за раст или пад интересовања. 
број означио „ништа од наведеног“ (А:34,6\%, Б:17,1\%). Занимљиво је да већи број испитаника групе Б, у односу на групу А, није задовољан организацијом наставе (А:7,7\%, Б:21,4\%) и што се за разлику од групе А, у групи Б може у малој мери приметити незадовољство предавачима (А:0\%, Б:2,4\%) и колегама студентима (А:0\%, Б:9,8\%). Ипак, ове разлике нису довољно велике како би могли да се извуку одређени закључци.

Мале разлике можемо уочити и у начину на који две групе посматрају прилике које имају за запослење након завршетка студија. Већина испитаника обе групе је исказала прилично оптимистичан став, изабравши одговор: „и у Србији и у иностранству постоје многе прилике за рад са грчким језиком“ (А:69,2\%, Б:61\%). Када је реч о запослењу, у просеку половина испитаника сваке групе сматра да ће са грчким језиком наћи запослење али да ће за то бити потребно време (A:50\%, Б:58,5\%). Група А исказује позитивнији став, па 30,8\% испитаника наводи да ће са грчким језиком наћи запослење одмах по завршетку студија, док се овај одговор може приметити само код 12,2\% испитаника групе Б.

\section{4. Закључак}

Циљ нашег рада било је истраживање могућих фактора који могу утицати на мотивацију студената у процесу усвајања модерног грчког језика. Задовољство је примећено различитим елементима студија, као што су предавачи, коришћење платформе Мудл, учионица или колеге студенти. Такође, исказано је генерално задовољство, које показује повећање у односу на почетак студија, као и испуњење очекивања у великој мери.

Приметили смо да је задовољство платформе Мудл, поред предавача, оно које се истакло међу одговорима анкетираних студената. Као што смо навели, интерактивност и доступност материјала путем ове платформе значајно утиче на перцепцију студената о предавањима и самим студијама, па можемо сматрати да има приметан позитиван утицај на њихову мотивацију за наставак студија. 
Када је реч о иницијалној жељи за уписивање студија, може се закључити да је више испитаника којима је грчки језик био прва жеља усмерено на њега и бира га као свој омиљени језик, док остали студенти језик воле али не искључиво, дајући можда предност неком другом језику, који је био њихов први избор. Ипак, када се ради о интересовању за грчки језик, оно се у подједнакој мери повећало код обе групе испитаника, односно у обе групе више од 70\% анкетираних наводи веће интересовање у односу на почетак студија. Сматрамо да је овај податак веома значајан јер показује да постоји подједнака могућност за мотивисање студената у будућности путем коришћења разних мотивационих стратегија, без обзира на њихову иницијалну мотивацију.

Општи закључак нашег истраживања је да на мотивацију студената могу утицати разноврсни фактори, међу којима се истиче значај увођења нових технологија, а конкретније платформе Мудл у наставу. Такође, сматрамо да без обзира на иницијалну мотивацију студенти имају подједнаке прилике за успех и повећање интересовања за област неохеленистике у будућности.

\section{ЛИТЕРАТУРА}

Ален, Симан 2007: Allen, I., Seaman, J. Online nation: Five years of growth in online learning. Needham, MA, USA: Sloan-C. (доступно на: https://bit.ly/2Wmi6SV, приступљено 23.11.2018)

Болигер, Василик 2009: Bolliger, D., Wasilik, O. Factors influencing faculty satisfaction with online teaching and learning in higher education, Distance Education, 30(1), 103-116. London, UK: Routledge. (доступно на: https://bit.ly/2ImeIOd, приступљено 24.10.2018)

Браунли-Кониерс 1996: Brownlee-Conyers, J. Voices from networked classrooms, Educational Leadership, 54(3), 34-37. Alexandria, VA, USA: ASCD.

Брофи 2013: Brophy, J. Motivating students to learn. London, UK: Routledge. (доступно на: https://bit.ly/2EtvOso, приступљено 13.11.2018)

Вучо, Недељковић, Митић (2007): Vučo, J./Nedeljković, M./Mitić, I. Italija s ove strane Jadrana. Motivacioni stavovi i kulturni stereotipi studenata italijanistike, u: J. Vučo (ur.), Savremene tendencije u 
nastavi jezika i književnosti, Beograd, Srbija: Filološki fakultet, 499507.

Гарднер 2000: Gardner, R. Correlation, causation, motivation, and second language acquisition, Canadian Psychology/Psychologie Canadienne, 41(1), 10-24. Ottawa, Canada: Canadian Psychological Association. (доступно на https://bit.ly/2W8zkzc, приступљено 14.12.2018)

Гарднер 2001: Gardner R. Language Learning Motivation: The Student, the Teacher, and the Researcher. Texas Papers in Foreign Language Education, 6(1), 1-18. Texas, USA: University of Texas at Austin. Foreign Language Education Center.

Гарднер, Масгорет, Тенант, Михић 2004: Gardner R., Masgoret, A., Tennant, J., Mihic, L. Integrative motivation: Changes during a yearlong intermediate-level language course, Language Learning, 54(1), 1-34. Michigan, USA: Language Learning Research Club, University of Michigan. (доступно на: https://bit.ly/2GX4m86, приступљено 20.09.2018)

Двајер 1996: Dwyer, D. A response to Douglas Noble: We're in this together, Educational Leadership, 54(3), 24-27. Alexandria, VA, USA: ASCD.

Дерњеј (1990): Dörnyei Z. Analysis of motivation components in foreign language learning, in: Conference Papers, 9th World Congress of Applied Linguistics, Thessaloniki, Greece, 15-21. (доступно на: https://bit.ly/2Wpk3y6, приступљено 25.12.2018)

Дерњеј (2003): Dörnyei Z./Skehan, P. Individual differences in second language learning, in: M. Long (Ed), The handbook of second language acquisition, Oxford, UK: Blackwell Publishing Ltd, 589-630. (доступно на: https://bit.ly/2IwKMlO, приступљено 20.10.2018)

Дерњеј 2001a: Dörnyei Z. New themes and approaches in second language motivation research, Annual Review of Applied Linguistics, 21, 43-59. Cambridge, UK: Cambridge University Press. (доступно на https:// bit.ly/2AQdCqH, приступљено 12.12.2018)

Дерњеј 2001б: Dörnyei, Z. Motivation strategies in the language classroom. Cambridge: Cambridge University Press.

Дерњеј 2005: Дерњеј, Z. The psychology of the language learner: Individual differences in second language acquisition. New Jersey, USA: Lawrence Erlbaum Associates.

Јаман, Арслан (2011): Yaman, S./Arslan, T. The use of Moodle as a supporter in a writing skill course: the methodology suggested with its application, in: Proceedings of the 3rd International Conference, Foreign Language Teaching in Tertiary Education, Athens, Greece: Dionikos, 443-448. 
Јулкунен 1989: Jülkunen, K. Situation-and task-specific motivation in foreign language learning and teaching. Doctoral dissertation. Kuopio: Finland: University of Joensuu.

Калвет 2000: Calvet, L. Le marche aux languages. Paris, France: Plon.

Келнер (2002): Kellner, D. New media and new literacies: Reconstructing education for the new millennium, in: Lievrouw, L., Livingstone, S. (Eds), The handbook of new media, London, UK: SAGE Publications, 90-104. (доступно на: https://bit.ly/2SUmF5b, приступљено 12.11.2018)

Ким, Бонк 2006: Kim, K., Bonk, C. The future of online teaching and learning in higher education, Educause quarterly, 29(4), 22-30. Washington, USA: EDUCAUSE Review. (доступно на: https://bit. ly/2DHF5xi, приступљено 15.11.2018)

Кисо 2006: Kissau, S. Gender differences in second language motivation: An investigation of micro-and macro-level influences, Canadian Journal of Applied Linguistics/Revue canadienne de linguistique appliquée, 9(1), 73-96. Ottawa, Canada: The Canadian Association

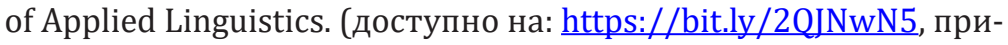
ступљено 18.11.2018)

Клемент (1980): Clément, R. Ethnicity, contact, and communicative competence in a second language, in: H. Giles, W. Robinson, P. Smith (Eds), Language: Social psychological perspectives, Oxford, UK: Pergamon, 147-154.

Клемент, Дерњеј, Ноелс 1994: Clément, R., Dörnyei, Z., Noels, K. Motivation, self-confidence, and group cohesion in the foreign language classroom, Language Learning, 44(3), 417-448. Michigan, USA: Language Learning Research Club, University of Michigan. (доступно на: https://bit.ly/2Ixb3An, приступљено 13.12.2018)

Костић (2018): Костић, А. „Буни се као Грк у апсу“ - студија о мотивацији, стереотипима и предрасудама при учењу модерног грчког језика, у: В. Половина, Б. Ковачевић (ур.), Примењена лингвистика, 19, Београд-Нови Сад: Друштво за примењену лингвистику Србије, 129-140.

Куретас, Вламис 2010: Kouretas, G., Vlamis, P. The Greek crisis: causes and implications, Panoeconomicus, 57(4), 391-404. http://www. panoeconomicus.org/index.php/jorunal. (доступно на: https://bit. ly/2XiXFD7, приступљено 21.11.2018)

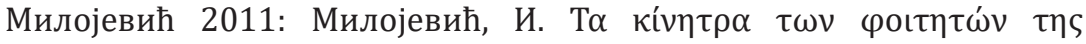

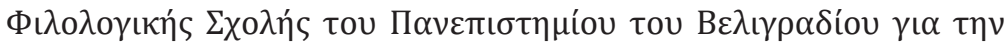

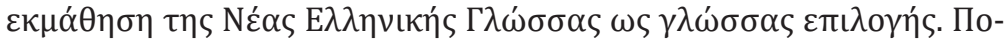

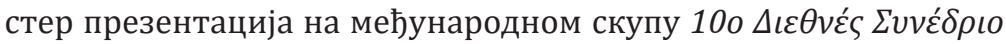




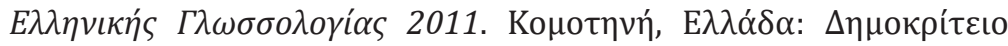

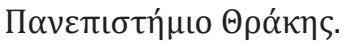

Мутавџић, Стојичић 2015: Mutavdzic, P., Stojicic, V. How Can Learning Lesser Used Languages Wide Out Our Frontiers? (A contribution to the theory and practice of intercultural communication), International Journal of Language, Translation and Intercultural Communication, 3, 60-67. Ioannina, Greece: University of Ioannina. (доступно на: https://bit.ly/2Zq5AyM, приступљено 25.11.2018) Новацик 1998: Nowaczyk, R. Student perception of multimedia in the undergraduate classroom, International Journal of Instructional Media, 25, 367-368. New York, USA: Baywood Pub. Co.

Петковић 2018: Петковић, Љ. Употреба платформе Mоодlе у реформисаној настави студија неохеленистике. Необјављени мастер рад. Београд, Србија: Филолошки факултет Универзитета у Београду. Санауи, Лапкин 1992: Sanaoui, R., Lapkin, S. A case study of an FSL senior secondary course integrating computer networking. The Canadian Modern Language Review, 43(3), 524-552. Toronto, Canada: University of Toronto Press.

Санчез, Уерос 2010: Sánchez, R., Hueros, A. Motivational factors that influence the acceptance of Moodle using TAM. Computers in Human Behavior, 26(6), 1632-1640. Amsterdam, Netherlands: Elsevier. (доступно на: https://bit.ly/2EdckY2, приступљено 30.10.2018)

Солдатић (2016): Soldatić, N. Teorijsko-metodološki prikaz primene „Moodle“ platforme u nastavi stranih jezika. Neobjavljeni master rad. Beograd, Srbija: Filološki fakultet Univerziteta u Beogradu.

Солдатић, Солдатић, Стојичић, Вучо (2012): Soldatić, D./Soldatić, N./ Stojičić, V./Vučo, J. Online priprema prijemnog ispita - jedno iskustvo, u: A. Vraneš, Lj. Marković, G. Aleksander (ur.), Digitalizacija kulturne i naučne baštine, univerzitetski repozitorijumi i učenje na daljinu. Knjiga 4: Učenje na daljinu i interaktivna nastava. Beograd, Srbija: Filološki fakultet, 35-51.

Степ-Грини 2002: Stepp-Greany, J. Student perceptions on language learning in a technological environment: Implications for the new millennium, Language Learning \& Technology, 6(1), 165-180. Michigan, USA: Michigan State University Center for Language Education and Research. (доступно на: https://bit.ly/2Xs9GpB, приступљено 26.12.2018)

Стојичић (2013): Стојичић, В. Грчка (ни)је само сунце и море, у: С. Гудурић (ур.), Језици и културе у времену и простору, II/1. Нови Сад, Србија: Филозофски факултет, 453-460. 
Стојичић 2010: Стојичић, В. Заједнички европски оквир за језике и реформисана настава савременог грчког језика. Необјављени мастер рад. Београд, Србија: Филолошки факултет Универзитета у Београду.

Стојичић, Гогас (2012): Stojicic, V./Gogas, Th. From 'public sphere' to the 'Crowd symbols'. How Serbian students of Greek Language perceive Greek culture, in: Approaches and Methods in Second and Foreign Language Teaching, Sarajevo, Bosna i Hercegovina: IBU Publications, 545-552.

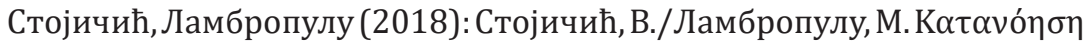

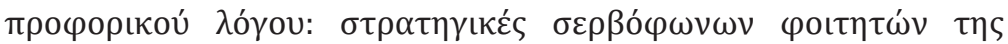

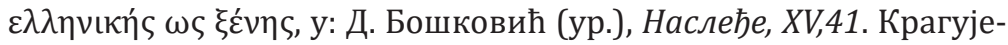
вац, Србија: Филолошко-уметнички факултет, 81-98.

Стојичић, Мутавџић (2011): Стојичић, В./Мутавџић, П. Мотивација грчких студената за учење савременог српског као страног језика, у: Весна Крајишник (ур.), Српски као страни језик у теорији и пракси II. Београд, Србија: Филолошки факултет БУ, 267-280.

Хои, Хјуз, Волкап 2008: Hoy, A., Hughes, M., Walkup, V. Psychology in education. Harlow, UK: Pearson Education.

Хорњак, С. (2012). Фактор мотивације у процесу усвајања страних језика, у: М. Ковачевић (ур.), Савремена проучавања језика и књижевности, III/1. Крагујевац, Србија: Филолошко-уметнички факултет, 443-452. 


\title{
Antonina Kostić
}

\section{MOTIVATIONAL FACTORS AND THE INFLUENCE OF NEW TECHNOLOGIES IN THE PROCESS OF LEARNING MODERN GREEK AS A FOREIGN LANGUAGE}

\begin{abstract}
Summary
The aim of this paper is to give an overview of the factors that can influence the students' motivation in the process of learning modern Greek as a foreign language. Particular attention was paid to the students' initial motivation and their initial preferences for undergraduate studies, as well as to the contribution of the use of new technologies, more specifically the Moodle platform, in foreign language teaching. First, some motivational theories are presented, as well as the role of new technologies at university level studies, while examining their implementation at the Faculty of Philology. In order to research these factors, a study was conducted among students of Neohellenic Studies at the Faculty of Philology, University of Belgrade. The paper presents the analysis of the results of the questionnaire in which students expressed their opinions about modern Greek language and specific elements of the learning situation at university level. The results indicate the importance of the implementation of new technologies in teaching as well as the contribution of the quality of studies, materials and lecturers for the increasement of the students' motivation for the continuance of their studies and their interest for the field.
\end{abstract}

